\title{
Brain antigens in functionally distinct antigen-presenting cell populations in cervical lymph nodes in MS and EAE
}

\author{
Marloes van Zwam • Ruth Huizinga • \\ Marie-José Melief • Annet F. Wierenga-Wolf • \\ Marjan van Meurs • Jane S. Voerman • \\ Knut P. H. Biber • Hendrikus W. G. M. Boddeke • \\ Uta E. Höpken - Christian Meisel • Andreas Meisel • \\ Ingo Bechmann - Rogier Q. Hintzen - Bert A. 't Hart • \\ Sandra Amor • Jon D. Laman - Leonie A. Boven
}

Received: 26 February 2008 / Revised: 8 November 2008 / Accepted: 10 November 2008 / Published online: 3 December 2008

(C) The Author(s) 2008. This article is published with open access at Springerlink.com

\begin{abstract}
Drainage of central nervous system (CNS) antigens to the brain-draining cervical lymph nodes (CLN) is likely crucial in the initiation and control of autoimmune responses during multiple sclerosis (MS). We demonstrate neuronal antigens within CLN of MS patients. In monkeys and mice with experimental autoimmune encephalomyelitis (EAE) and in mouse models with non-inflammatory CNS damage, the type and extent of CNS damage was associated
\end{abstract}

Authors JDL and LAB share senior authorship.

The authors have no conflict of interest.

M. van Zwam • R. Huizinga • M.-J. Melief •

A. F. Wierenga-Wolf $\cdot$ M. van Meurs ·J. S. Voerman •

J. D. Laman $(\square) \cdot$ L. A. Boven

Department of Immunology, Ee800, Erasmus MC,

P.O. Box 2040, 3000 CA Rotterdam, The Netherlands

e-mail: j.laman@erasmusmc.nl

R. Huizinga $\cdot$ B. A. 't Hart

Department of Immunobiology,

Biomedical Primate Research Centre,

Rijswijk, The Netherlands

K. P. H. Biber $\cdot$ H. W. G. M. Boddeke

Department of Medical Physiology,

University Medical Centre Groningen,

Groningen, The Netherlands

U. E. Höpken

Department of Tumor Genetics and Immunogenetics,

Max Delbrück Center for Molecular Medicine,

Berlin, Germany

C. Meisel

Department of Immunology, Charité Universitaetsmedizin Berlin,

Berlin, Germany with the frequencies of CNS antigens within the cervical lymph nodes. In addition, CNS antigens drained to the spinal-cord-draining lumbar lymph nodes. In human MS CLN, neuronal antigens were present in pro-inflammatory antigen-presenting cells (APC), whereas the majority of myelin-containing cells were anti-inflammatory. This may reflect a different origin of the cells or different drainage mechanisms. Indeed, neuronal antigen-containing cells in

\section{A. Meisel}

Department of Experimental Neurology,

Charité Universitaetsmedizin Berlin,

Berlin, Germany

I. Bechmann

Dr Senckenbergische Anatomie,

Institute of Clinical Neuroanatomy,

Goethe University,

Frankfurt, Germany

\section{R. Q. Hintzen}

Department of Neurology,

Erasmus MC,

Rotterdam, The Netherlands

\section{S. Amor}

Department of Pathology, VU Medical Centre,

Amsterdam, The Netherlands

M. van Zwam $\cdot$ R. Huizinga $\cdot$ M.-J. Melief $\cdot$

A. F. Wierenga-Wolf $\cdot$ M. van Meurs · J. S. Voerman •

R. Q. Hintzen · B. A. 't Hart · J. D. Laman · L. A. Boven

MS Centre ErasMS,

Rotterdam, The Netherlands 
human CLN did not express the lymph node homing receptor CCR7, whereas myelin antigen-containing cells in situ and in vitro did. Nevertheless, CLN from EAE-affected CCR7-deficient mice contained equal amounts of myelin and neuronal antigens as wild-type mice. We conclude that the type and frequencies of CNS antigens within the CLN are determined by the type and extent of CNS damage. Furthermore, the presence of myelin and neuronal antigens in functionally distinct APC populations within MS CLN suggests that differential immune responses can be evoked.

Keywords Neuroinflammation · Immune regulation . Autoreactive T cells $\cdot$ Tolerance $\cdot$ Chemokines $\cdot$ Cytokines

$\begin{array}{ll}\text { Abbreviations } \\ \text { APC } & \text { antigen-presenting cell } \\ \text { CFA } & \text { complete Freund's adjuvant } \\ \text { CLN } & \text { cervical lymph node } \\ \text { CNS } & \text { central nervous system } \\ \text { CSF } & \text { cerebrospinal fluid } \\ \text { EAE } & \text { experimental autoimmune encephalomyelitis } \\ \text { ECL } & \text { entorhinal cortex lesion } \\ \text { FNA } & \text { facial nerve axotomy } \\ \text { IL-1ra } & \text { IL-1 receptor antagonist } \\ \text { LLN } & \text { lumbar lymph nodes } \\ \text { MAP-2 } & \text { microtubule-associated protein-2 } \\ \text { MCAO } & \text { middle cerebral artery occlusion } \\ \text { MHC } & \text { major histocompatibility complex } \\ \text { MOG } & \text { myelin oligodendrocyte glycoprotein } \\ \text { MS } & \text { multiple sclerosis } \\ \text { NF-L } & \text { neurofilament light } \\ \text { NF-H } & \text { neurofilament heavy } \\ \text { NSE } & \text { neuron-specific enolase }\end{array}$

\section{Introduction}

Irreversible neuronal damage is a major pathological feature of multiple sclerosis (MS) and ranges from mild pathology to complete axonal transection $[1,2]$. The cause of neuronal damage is not yet elucidated, but autoreactive $\mathrm{B}$ and $\mathrm{T}$ cells directed against neuronal antigens could conceivably be instrumental [3]. Indeed, MS patients have increased circulating antibody levels against the neuronal proteins neurofilament light (NF-L) and neurofilament heavy (NF-H) [4-6] in serum and against the medium subunit of neurofilament in cerebrospinal fluid (CSF) [7]. In addition, $\mathrm{T}$ cells from MS patients proliferate in response to the neuronal antigens synapsin and neuron-specific enolase (NSE) [8, 9]. In mice, T-cell-mediated autoimmunity against neuronal antigens leads to central nervous system (CNS) inflammation and experimental autoimmune encephalomyelitis (EAE) symptoms [10-14].
Autoreactive lymphocytes against myelin proteins and likely also against neuronal antigens are recruited into the CNS [2]. Where in the body these lymphocytes initially are activated is still unclear. This is a critical issue, in view of possible therapeutic interventions aiming to limit activation of autoreactive $\mathrm{T}$ cells. Under experimental conditions, dendritic cells activate naïve $\mathrm{CD}^{+}$transgenic $\mathrm{T}$ cells directed against proteolipid protein (PLP) ${ }_{139-151}$ within the CNS [15]. However, the classical view on the initiation of naïve $\mathrm{T}$ cell activation holds that antigens or antigencontaining antigen-presenting cells (APC) must be transferred to the brain-draining cervical lymph nodes (CLN) to effectively activate naïve $\mathrm{T}$ cells $[16,17]$. CNS-resident APC subsequently reactivate these antigen-experienced $\mathrm{T}$ cells and allow them to exert their effector functions within the target organ $[18,19]$. A crucial role of the CLN in CNS inflammation is supported by the observation that surgical removal of the CLN reduced the number of brain lesions in cryolesion-enhanced EAE in the rat [20]. Furthermore, myelin basic protein, PLP, and neutral lipid-containing APC are present in the CLN of MS patients and EAEaffected marmoset and rhesus monkeys [21, 22]. These APC stimulated myelin-specific $\mathrm{T}$ cell proliferation [21], demonstrating that myelin drainage to the CLN during demyelinating disease results in the activation of autoreactive $\mathrm{T}$ cells.

We hypothesize that drainage of neuronal antigens from the target organ to the CLN may be similarly involved in initiating or modulating neuron-specific immune responses. We have analyzed whether brain-derived neuronal antigens are present in CLN of MS patients and of selected animal models with different degrees of CNS damage. In addition, we determined whether these antigens are present in distinct APC subsets, which may influence $\mathrm{T}$ cell activation.

\section{Materials and methods}

\section{MS tissues}

Human jugular (deep) CLN and supraclavicular CLN were taken from MS patients with active disease at autopsy. Chronic inactive and active plaques were present in the cerebrum of these patients. The MS patients died of non-MSrelated causes. In addition, CLN were taken from controls without neurological disease at autopsy by the Netherlands Brain Bank (coordinator Dr. R. Ravid). CLN were snapfrozen in liquid nitrogen and stored at $-80^{\circ} \mathrm{C}$ until use.

\section{EAE tissues}

All animal studies in the current study followed the principles of animal care and were approved by local 
ethical committees based on national legislation. Tissues were obtained from animals that were used for studies designed for other purposes, thus avoiding the sacrifice of animals for the present study only.

Deep CLN were isolated from rhesus monkeys (Macaca mulatta) with acute EAE $(n=5)$ which was induced as described [23] and from rhesus monkeys with collageninduced arthritis $(n=3)$ [24]. Deep CLN were also isolated from common marmoset monkeys (Callithrix jacchus) during chronic EAE $(n=5)$ [25, 26]. Control CLN were from marmosets $(n=2)$ immunized with ovalbumin in complete Freund's adjuvant (CFA) [21]. The monkeys were housed at the Biomedical Primate Research Center (BPRC, Rijswijk, the Netherlands).

Deep and superficial CLN were isolated from Biozzi $\mathrm{ABH}\left(\mathrm{H}-2^{\mathrm{dq} 1}\right)$ mice, obtained from stock bred at the BPRC, at the acute phase of disease $(n=3)$ and during the first relapse $(n=3)$. EAE was induced by immunization with spinal cord homogenate or myelin oligodendrocyte glycoprotein $(\mathrm{MOG})_{8-21}$ in CFA as described $[27,28]$. Deep and superficial CLN were also isolated from CCR7-deficient $(n=4)$ and wild-type mice $(n=4)$ [29] with chronic EAE, obtained from stock bred at the animal facility of the Max Delbrück Center for Molecular Medicine (Berlin, Germany). Chronic EAE was induced by s.c. injections of $200 \mu \mathrm{g}$ $\mathrm{MOG}_{35-55}$ emulsified in CFA (Difco Laboratories) containing $400 \mu \mathrm{g}$ of Mycobacterium tuberculosis. Mice received i.v. injections with $200 \mathrm{ng}$ Bordetella pertussis toxin (Sigma) on days 0 and 2 postimmunization. The CCR7-deficient mice used in these experiments had been backcrossed to C57BL/6 mice for eight generations.

All animals were examined daily for clinical symptoms of EAE as described [21, 25, 28, 30]. Tissues were snapfrozen in liquid nitrogen and stored at $-80^{\circ} \mathrm{C}$.

\section{Non-inflammatory CNS damage models}

Ischemia was induced in C57BL/6 mice (BgVV) by occlusion of the left middle cerebral artery (MCAO) [31]. The MCAO did not exceed $60 \mathrm{~min}$. CLN were isolated $24 \mathrm{~h}$ $(n=5)$ and $72 \mathrm{~h}(n=5)$ after MCAO. Entorhinal cortex lesion (ECL) and facial nerve axotomy (FNA) were performed as described [32] in C57BL/ 6 mice ( $n=5$ and $n=3$, respectively; Charles River). CLN were isolated 7 days later.

Demyelination was induced chemically by cuprizone (Sigma-Aldrich) in SJL/J mice ( $n=3$; Janvier) and C57BL/6 mice ( $n=3$; Harlan) as described [33]. These animals were representative animals within a larger experiment designed for other purposes, consisting of $18 \mathrm{SJL} / \mathrm{J}$ mice and 18 C57BL/6 mice. Five to 6 weeks after start of treatment with cuprizone, superficial CLN, deep CLN, and lumbar lymph nodes (LLN) were isolated. All tissues were snap-frozen and stored at $-80^{\circ} \mathrm{C}$.
Immunohistochemistry

Immunohistochemistry was performed as described [34, 35]. Primary antibodies were polyclonal rabbit antibodies against transcription growth factor (TGF)- $\beta$ (Santa Cruz) and NF-L (Abcam), and monoclonal mouse antibodies against NSE (MIG M3; Abcam), microtubule-associated protein-2 (MAP-2; HSM 5; Pierce Biotechnology), NF-H (SMI-32; Sternberger Monoclonals), PLP (J1/06 [36]), HLA-DP/DQ/DR (CR3/43; DAKO), CD40 (5D12; dr. M. de Boer), interleukin 1 receptor antagonist (IL-1ra; A71B6D11; Bioscource), tumor necrosis factor (TNF)- $\alpha$ (61E71; U Cytech), IL-12p40/p70 (C8.6; BD), and CCR7 (2H4; BD).

Primary antibodies were detected by biotinylated donkey anti-rabbit immunoglobulin (Ig; Amersham) or rabbit antimouse Ig (DAKO) and horseradish peroxidase (HRP)conjugated avidin-biotin complex (DAKO). HRP activity was revealed with 3-amino-9-ethylcarbazole (SigmaAldrich), which resulted in a red precipitate. Brain or spinal cord sections from the same species were used as positive control tissue. As negative controls, sections were incubated with isotype-matched primary antibodies of irrelevant specificity, or the primary antibody was omitted.

\section{Immunofluorescence}

Double labeling was performed using immunofluorescence as described [37]. Sections were incubated with primary antibodies for $1 \mathrm{~h}$ at room temperature (RT), followed by fluorescein isothiocyanate (FITC)- or tetramethylrhodamine isothiocyanate (TRITC)-labeled rabbit anti-mouse Ig (DAKO) or TRITC-labeled swine anti-rabbit Ig (DAKO) for $30 \mathrm{~min}$ at RT. Subsequently, sections were incubated for $1 \mathrm{~h}$ at RT with Alexa594-labeled anti-MAP-2 (IgG1 Zenon labeling kit, Molecular Probes) or with anti-MOG for $1 \mathrm{~h}$ at RT, followed by biotinylated anti-IgG2a (SBA) for $30 \mathrm{~min}$ at RT and FITC-labeled streptavidin (DAKO) for $1 \mathrm{~h}$ at RT. Sections were mounted in glycerol-Tris-4',6-diamidino-2phenylindole (DAPI; $50 \mu \mathrm{g} / \mathrm{ml}$; Molecular Probes).

As controls, single stainings were performed following the procedure described above but with omission of one of the primary antibodies used in the double staining. Human reactive tonsil or brain was used as positive control tissue. Negative controls are described above.

CCR7 expression by myelin-laden human monocyte-derived macrophages

Monocytes from healthy donors were routinely purified and cultured [38]. For the current study, experiments were performed with cells from two individual donors that responded representatively for at least 50 donors assessed 
in the preceding years. Monocyte-derived macrophages were seeded into 24 -well tissue culture plates at $2 \times 10^{5}$ cells per well. After $24 \mathrm{~h}$, non-adherent cells were removed and the remaining cells were incubated with human myelin [39] for the indicated times. Control macrophages were obtained from the same donor.

Total mRNA was extracted from cell cultures as described [38]. CCR7 mRNA expression was analyzed by real-time polymerase chain reaction using the iCycler (Bio$\mathrm{rad}$ ) and the iQ SYBR Green supermix (Bio-rad). The housekeeping gene HPRT1 was used for normalization. The following primers were used: $5^{\prime}$-TGGTCGTGGTCTT CATAGTC- ${ }^{\prime}$ ' and 5'-CAGGTGCTACTGGTGATGTT- ${ }^{\prime}$ ' for CCR7 and 5'-TGACACTGGCAAAACAATGCA-3' and 5'AGCTTGCTGGTGAAAAGGACC-3' for HPRT1.

CCR7 surface expression by human monocyte-derived macrophages was determined using flow cytometry. Fc receptors were blocked using 20\% Fc-block (Miltenyi Biotec) and CCR7 was stained using phycoerythrin-labeled mouse anti-CCR7 (150503; R\&D Systems) for $30 \mathrm{~min}$ on ice. An isotype-matched antibody of irrelevant specificity was used as negative control. Samples were analyzed on a FACSCalibur flow cytometer using CellQuest analysis software (Becton Dickinson).

$\mathrm{T}$ cell proliferation assay

Deep CLN, superficial CLN, and LLN were isolated from C57BL/6 mice with chronic EAE and from Biozzi ABH mice with relapsing-remitting EAE. EAE in C57BL/6 mice was induced by immunization with $200 \mu \mathrm{g} \mathrm{MOG}_{35-55}$ in CFA [30] and in Biozzi ABH mice as described above. Lymph nodes from five to ten EAE-affected animals were pooled per experiment to obtain enough cells for restimulation. A single cell suspension was obtained by passing the lymph nodes through a $70-\mu \mathrm{m}$ gauze. Lymph node cells, $2 \times 10^{5}$, were seeded into 96 -well round-bottomed plates (Nunc) and stimulated with the indicated concentrations of $\mathrm{MOG}_{8-21}, \mathrm{MOG}_{35-55}$ (both from Advanced Biotechnology Center, Imperial College London), recombinant mouse NFL (rmNF-L) [40], or ovalbumin (Worthington). After 4 days, $\mathrm{T}$ cell proliferation was determined by incorporation of $\left[{ }^{3} \mathrm{H}\right]$-thymidine for $18 \mathrm{~h}$ (Amersham Biosciences) as described [30].

Image analysis

The area of the sections was measured using a VIDAS-RT image analysis system (Kontron Elektronic/Carl Zeiss) to obtain the number of antigen-positive cells per square millimeter. Differences in number of neuronal antigencontaining cells in CLN between treatment groups were determined by a two-tailed Mann-Whitney test using the statistical software program SPSS, version 11.0. A significance level of 0.05 was used.

\section{Results}

Presence of neuronal antigens within the CLN of MS patients

To determine the presence of neuronal antigens in CLN of MS patients with active disease, cryosections were stained with antibodies specific for three neuronal antigens: MAP-2, NSE, and NF-H. Cells containing each of the neuronal antigens were detectable in CLN from all MS patients, which were predominantly large cells located in the medulla of the lymph node with a morphology resembling macrophages. Neuronal antigen-containing cells were also found in the paracortex, where dendritic cells and $\mathrm{T}$ cells are located (Fig. 1a-c).

As previously described, neuronal antigen-containing cells were also present in CLN of control subjects (Fig. 1d-f) $[41,42]$. To investigate whether the presence of neuronal antigens in CLN of MS patients was the result of neuronal damage in the CNS or the result of expression by cells in the CLN, neuronal antigen-containing cells were quantified and compared with the number of neuronal antigencontaining cells in CLN of control subjects without neurological disease. As the numbers of MAP-2-, NSE-, and NF-H-positive cells in CLN of MS patients and control subjects were not statistically different (Fig. 1d-f), we could not definitively conclude that increased neuronal damage within the CNS resulted in increased neuronal antigen drainage to CLN. Hence, we performed an elaborate analysis in a variety of EAE models and in animal models of non-inflammatory CNS damage (Table 1).

Presence of neuronal antigen-containing cells in CLN of EAE-affected animals reflects the intensity of neuronal damage

It has been well established that the rhMOG-induced EAE model in common marmoset monkeys is characterized by chronic progressive disease with limited axonal destruction, whereas the same EAE model in rhesus monkeys follows a short-lasting acute disease course with extensive axonal destruction [43]. In CLN of EAE-affected marmoset monkeys, NSE- and NF-H-containing cells were observed (Fig. 2a,b). Quantification revealed a higher, but not significantly different, number of neuronal antigen-containing cells in CLN of EAE-affected marmosets as compared to CFA controls (Fig. 2c,d). In contrast, the CLN of EAE-affected rhesus monkeys contained significantly more MAP-2 and 

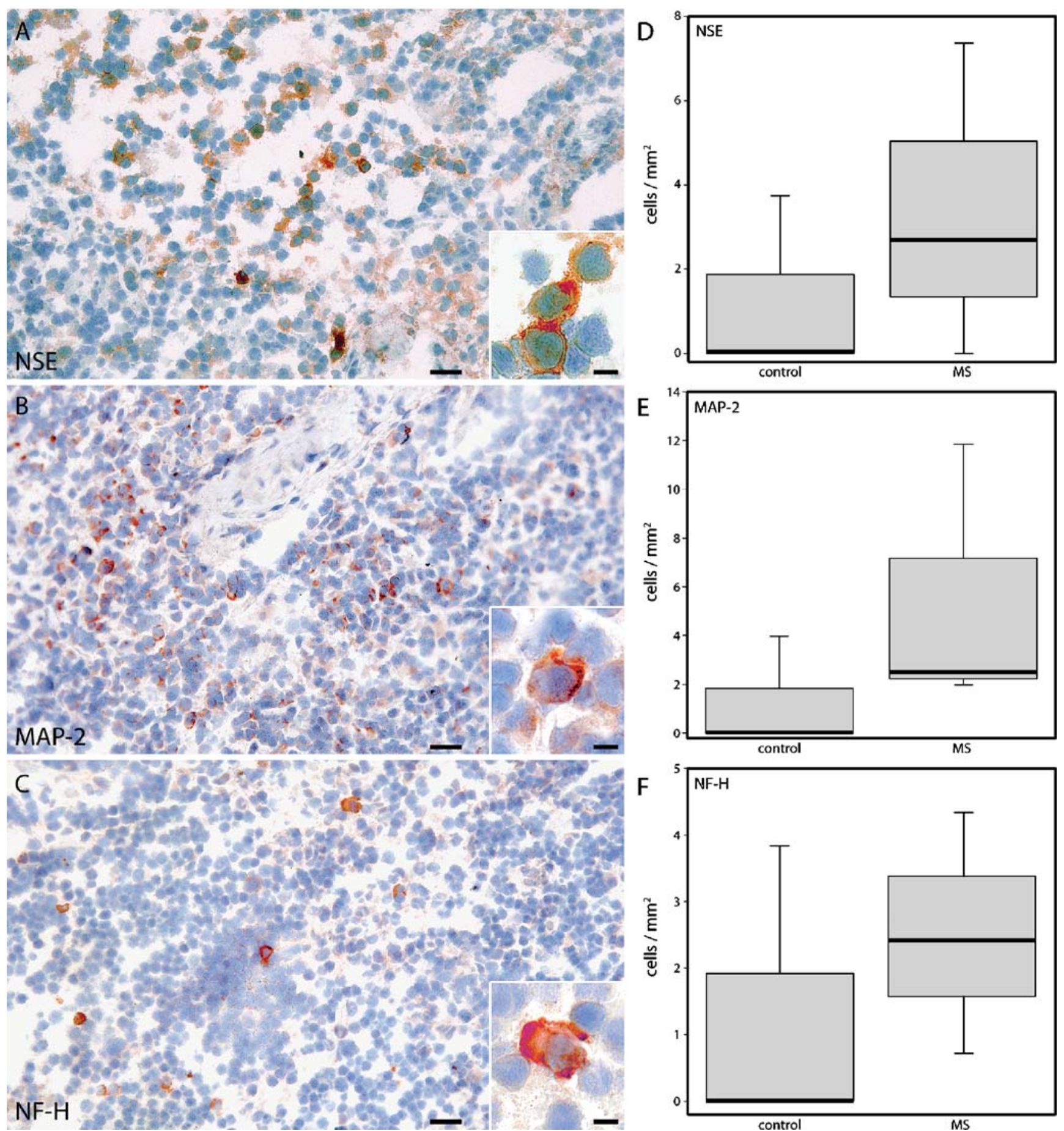

Fig. 1 Neuronal antigens drain to the CLN in MS. CLN of MS patients contain cells that are positive for the neuronal antigens NSE (a), MAP-2 (b), and NF-H (c). Scale bars $20 \mu \mathrm{m}$; insert $5 \mu \mathrm{m}$. Quantification of the number of MAP-2 (d), NSE (e), and NF-H (f) positive cells demonstrated a higher, but not significantly different, number of neuronal antigen-containing cells in CLN of three MS patients than in CLN of three controls without neurological disease. Three sections from CLN of each patient were quantified for each neuronal antigen. Results are shown as box plots with medians, 25th and 75 th percentiles as boxes, tenth and 90th percentiles as whiskers
NF-H-containing cells (Fig. 2e,f), than the CLN of CFA controls ( $p<0.05$; Fig. 2g,h).

The neuronal antigen NF-L was detected in deep CLN from EAE-affected Biozzi ABH mice with clinical EAE, but only rarely in superficial CLN (Fig. 2i). This EAE model is characterized by a first peak of acute disease with inflammation and axonal injury, followed by one or more relapses. As an example, Fig. 2k shows the typical 
Table 1 Characteristics of MS and the animal models used in this study

\begin{tabular}{|c|c|c|c|}
\hline Disease & Selected characteristics for this study & Demyelination & Neuronal damage \\
\hline Human MS & Myelin antigens in CLN (neutral lipids, MBP, PLP) [21] & Present [2] & Present [2] \\
\hline Marmoset EAE & $\begin{array}{l}\text { Chronic EAE } \\
\text { Myelin antigens in CLN (neutral lipids, MBP, PLP) [21] }\end{array}$ & Present [43] & Limited [43] \\
\hline Rhesus EAE & $\begin{array}{l}\text { Acute EAE } \\
\text { Myelin antigens in CLN (MBP, PLP) [21] }\end{array}$ & $\begin{array}{l}\text { Dramatic destruction of } \\
\text { myelin [43] }\end{array}$ & $\begin{array}{l}\text { Dramatic destruction } \\
\text { of axons [43] }\end{array}$ \\
\hline Biozzi ABH EAE & Chronic relapsing EAE & $\begin{array}{l}\text { Little in acute phase, } \\
\text { abundant in relapse [54] }\end{array}$ & $\begin{array}{l}\text { Present in every } \\
\text { phase of disease [54] }\end{array}$ \\
\hline C57BL/6 EAE & Chronic EAE & Present [55] & Present [55] \\
\hline Cuprizone & Chemically induced demyelination without clinical disease & $\begin{array}{l}\text { Extensive } \\
\text { demyelination [33] }\end{array}$ & $\begin{array}{l}\text { Little neuronal } \\
\text { damage [46] }\end{array}$ \\
\hline MCAO & Ischemic lesions in the cortex, striatum, and hippocampus & Massive myelin loss [31] & $\begin{array}{l}\text { Massive neuronal } \\
\text { loss [31] }\end{array}$ \\
\hline ECL & $\begin{array}{l}\text { Perforant pathway is stereotactically lesioned, leading to } \\
\text { anterograde axonal degeneration within dentate gyrus of the } \\
\text { hippocampus [56] }\end{array}$ & $\begin{array}{l}\text { Limited since the perforant } \\
\text { pathway is not myelinated }\end{array}$ & $\begin{array}{l}\text { Present in } \\
\text { hippocampus [45] }\end{array}$ \\
\hline FNA & $\begin{array}{l}\text { Blood brain barrier remains intact; retraction of the motoneurons } \\
\text { in the brainstem [44] }\end{array}$ & $\begin{array}{l}\text { Limited since the facial } \\
\text { nucleus is not myelinated }\end{array}$ & Limited [57] \\
\hline
\end{tabular}

relapsing-remitting disease course in this model. CLN isolated during acute EAE as well as during the first relapse had significantly more NF-L-containing cells than CFAimmunized control mice $(p<0.05$; Fig. $2 \mathrm{j})$. We observed similar numbers of NF-L-containing cells in the first EAE episode and the subsequent relapse.

As in CLN of MS patients, neuronal antigen-containing cells in the CLN of EAE-affected mice and monkeys were large macrophage-like cells which were located in the medulla of the lymph node and, although in lower numbers, in the paracortex.

Drainage of CNS antigens to the CNS-draining lymph nodes is reflected by the extent and type of CNS damage

To further assess whether the extent and also the type of CNS insult determines drainage of CNS compounds and to investigate drainage routes of CNS antigens in mice, we used different mouse models with non-inflammatory CNS damage. The MCAO model is characterized by massive ischemic lesions in the cortex, striatum, and the hippocampus [31]. Superficial as well as deep CLN isolated $24 \mathrm{~h}$ after MCAO contained numerous PLP- and NF-L-containing cells (Fig. 3b,c). This number was reduced after $72 \mathrm{~h}$ (Fig. 3b,c), indicating rapid and transient drainage following CNS damage. In CLN isolated from mice with ECL and FNA, few PLP- and NF-L-containing cells were observed in the CLN (Fig. 3b,c), reflecting the mild CNS damage in these models [44, 45]. The cuprizone model is characterized by extensive CNS demyelination induced by cuprizone, which selectively kills oligodendrocytes [33]. Little drainage of the myelin antigen PLP to the superficial CLN was noticed (Fig. 3a, b). In contrast, the deep CLN of both
SJL/J mice (Fig. 3a,c) as well as C57BL/6 mice (data not shown) contained significantly higher numbers of PLPcontaining cells $(p<0.001)$. We also detected myelin antigens in the LLN (Fig. 3a,c), reflecting drainage of antigens from the spinal cord. Only few NF-L-containing cells were observed in the CLN of cuprizone-treated mice (Fig 3b,c), which is in line with the limited neuronal damage in this model [46].

Neuronal antigen-containing cells have an APC phenotype

Although the majority of neuronal antigen-containing cells in MS CLN were located in the medulla of the lymph node, such cells were also found in the paracortex (Fig. 1a-c), where APC interact with naïve $\mathrm{T}$ lymphocytes. We therefore investigated whether neuronal antigen-containing cells in MS CLN express APC markers. As expected in a secondary lymphoid organ, numerous cells in the CLN expressed major histocompatibility complex (MHC) class II and CD40 of which only a fraction contained the neuronal antigen MAP-2. However, almost all (90-100\%) MAP-2positive cells expressed MHC class II (Fig. 4a) and the costimulatory molecule CD40 (Fig. 4b). This indicates that neuronal antigen-containing cells are APC, such as dendritic cells or macrophages, which may be involved in the induction of autoimmunity against neuronal antigens or conversely in the control of autoreactivity.

T cells in CLN proliferate to MOG peptide, without evident epitope spreading to NF-L

The localization of neuronal antigens in APC within the CLN may activate autoreactive T cells. This was tested in 

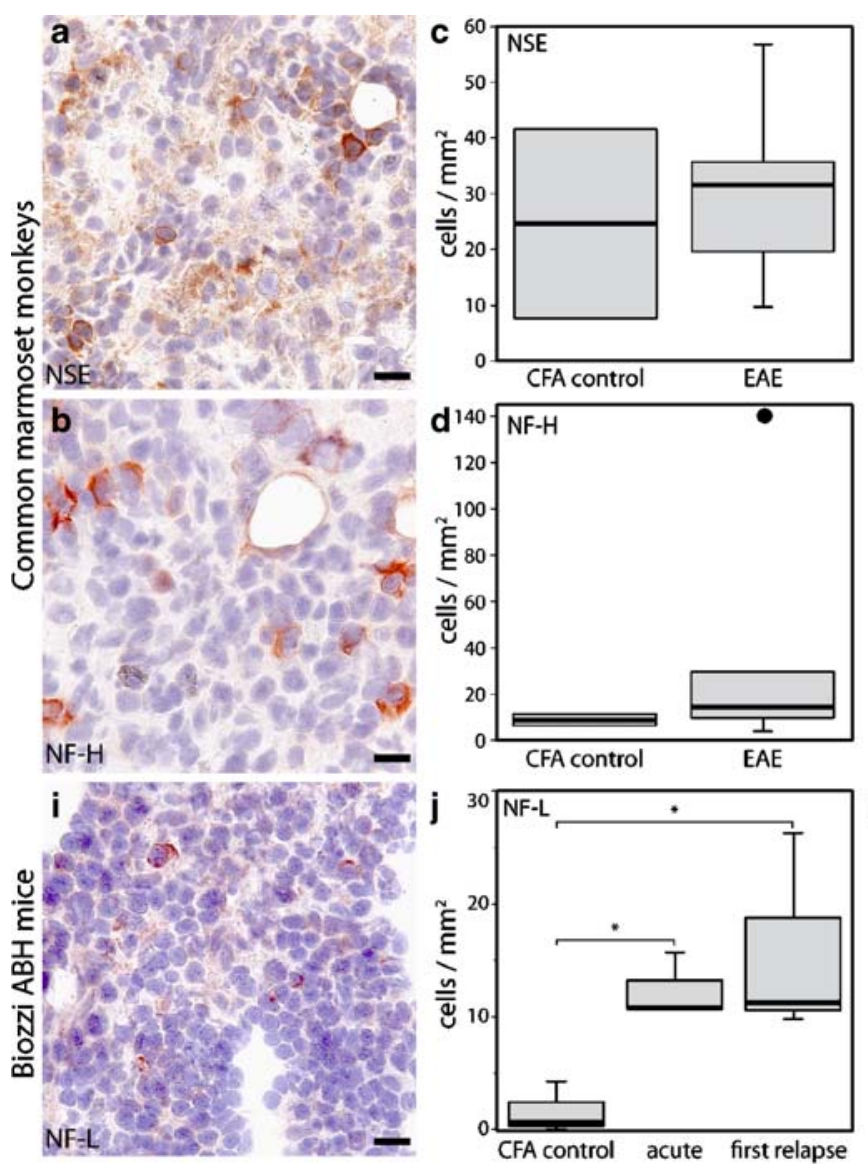

Fig. 2 The presence of neuronal antigen-containing cells during EAE reflects the extent of neuronal damage within the CNS. CLN of EAEaffected common marmoset monkeys contain NSE (a) and NF-H (b) positive cells. More NSE (c) and NF-H (d) positive cells were observed in CLN of five marmosets with EAE as compared to two CFA-immunized control marmosets, although this difference was not significant. In CLN of EAE-affected rhesus monkeys, MAP-2 (e) and NF-H (f) positive cells were found. Quantification of MAP-2 (g) and $\mathrm{NF}-\mathrm{H}$ (h) positive cells revealed a significantly higher number of cells in CLN of five rhesus monkeys with EAE than in CLN of three

three independent experiments. Two experiments were using $\mathrm{C} 57 \mathrm{BL} / 6$ mice in which EAE was induced by injection with $\mathrm{MOG}_{35-55}$ ( $n=5-10$ per experiment). One additional experiment was using Biozzi ABH mice $(n=10)$ in which EAE was induced by injection with $\mathrm{MOG}_{8-21}$. Figure 5 shows a representative experiment, in which we observed dose-dependent $\mathrm{T}$ cell proliferation against the immunizing peptide $\mathrm{MOG}_{35-55}$ in deep CLN, superficial CLN as well as in LLN. CLN and LLN from mice immunized with $\mathrm{MOG}_{8-21}$ demonstrated quantitatively similar proliferation against $\mathrm{MOG}_{8-21}$ (data not shown). No proliferation against the irrelevant control antigen OVA was seen. We did not detect NF-L-specific T cell proliferation in the two EAE models used for these experiments.

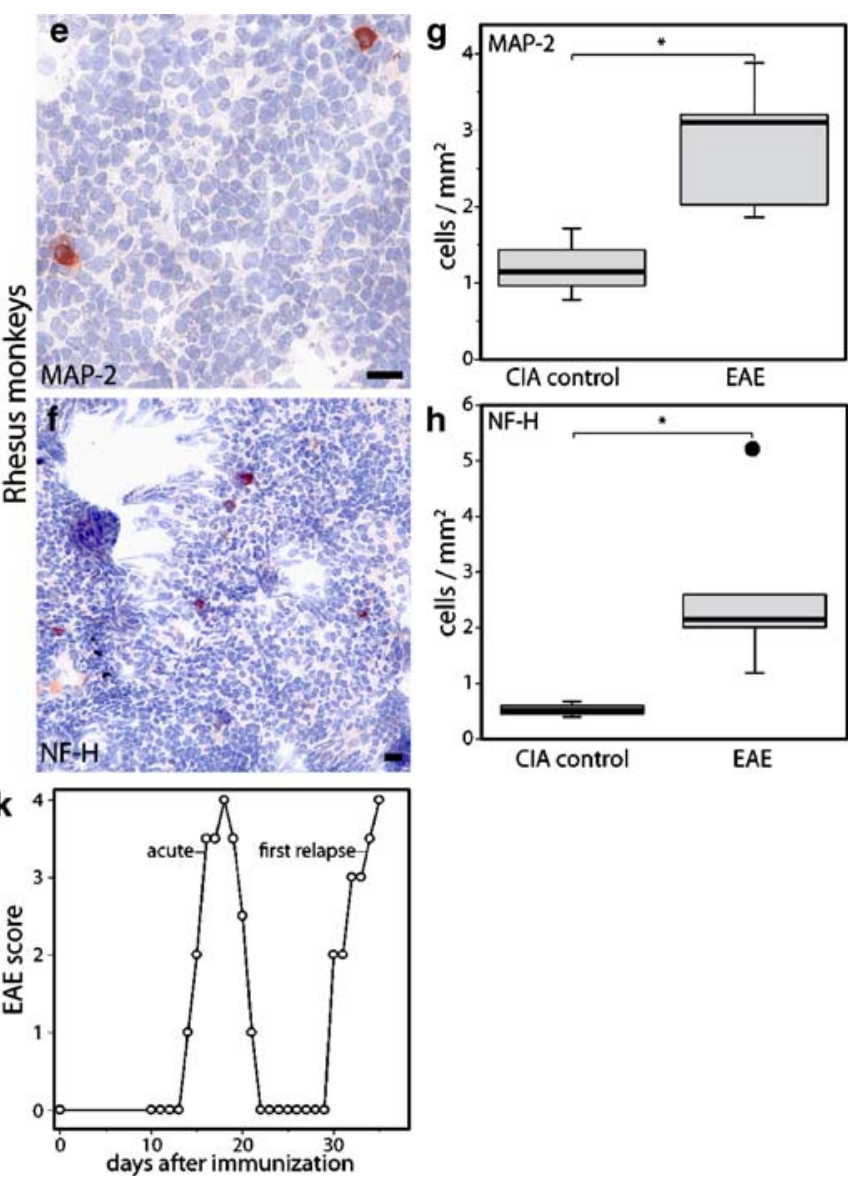

collagen-induced arthritis $(C I A)$ control monkeys $\left({ }^{*} p<0.05\right)$. NF-Lpositive cells were present in the deep CLN of EAE Biozzi ABH mice (i). Deep CLN from three animals with acute disease as well as from three mice in the first relapse contained significantly more NF-Lpositive cells than CLN from three CFA-immunized control mice ( $\mathbf{j}$; $* p<0.05)$. EAE scores from one representative animal out of three are shown (k). Three sections from CLN of each monkey and four sections from CLN of each mouse were quantified for each neuronal antigen. Results are given as box plots as described in Fig. 1 with extreme values as filled circles. Scale bars $10 \mu \mathrm{m}$

Differential expression of pro- and anti-inflammatory molecules by myelin-containing versus neuronal antigen-containing cells

Myelin-laden myeloid cells in MS brain with foamy appearance demonstrate a strong anti-inflammatory phenotype in situ and in vitro, implying a possible role in the resolution of local inflammation during MS [38]. To assess whether this also holds true for myelin antigen-containing cells and neuronal antigen-containing cells in CLN of MS patients, we determined the expression of pro- and antiinflammatory molecules. The majority of MOG-containing cells $(90-100 \%)$ coexpressed the anti-inflammatory molecules IL-1ra (Fig. 6a) and TGF- $\beta$ (Fig. 6b), whereas only a minority of the cells $(2-30 \%)$ expressed the pro- 


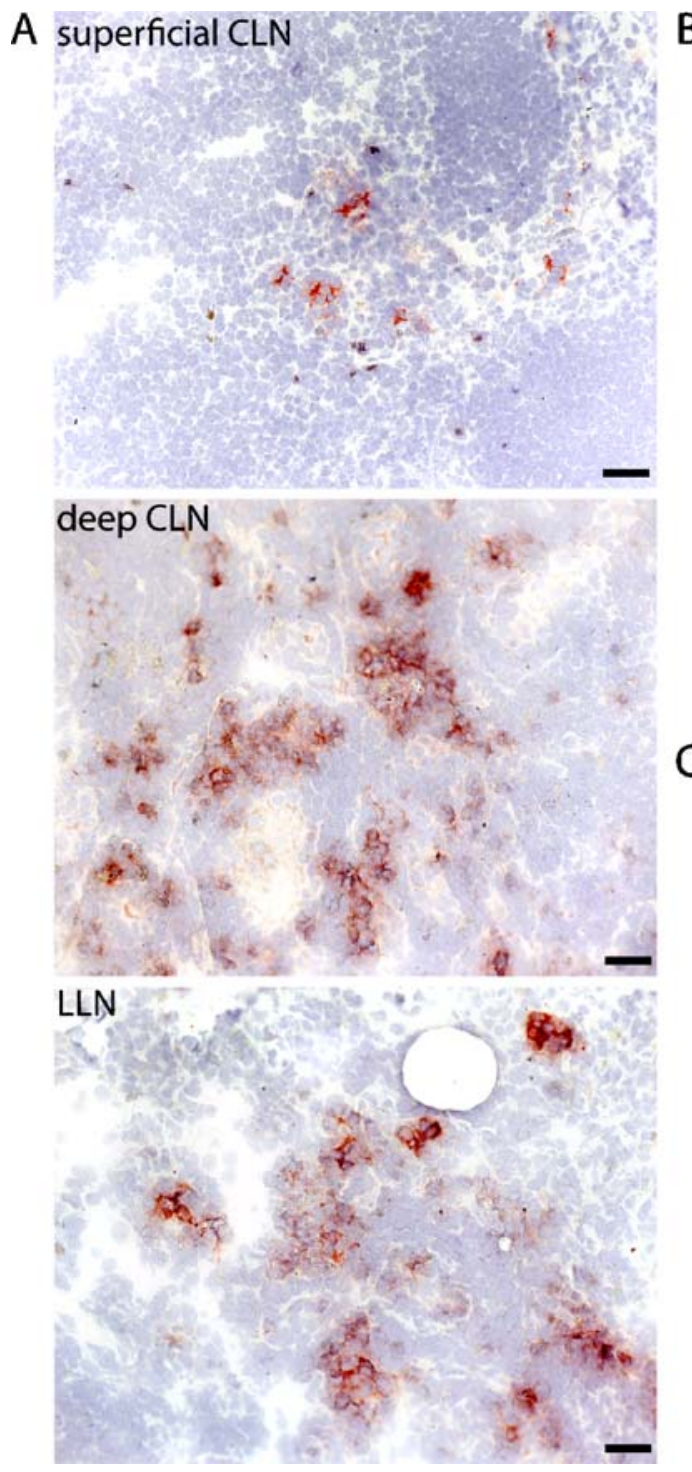

Fig. 3 The type and extent of non-inflammatory CNS damage correlates with the frequencies of CNS antigens in the CNS-draining lymph nodes. PLP-containing cells in the superficial CLN, deep CLN, and the spinal cord-draining LLN of cuprizone-treated SJL/J mice. Scale bars $50 \mu \mathrm{m}$ (a). Quantification of the number of PLP- and NFL-containing cells in the superficial CLN (b) and deep CLN (c).

inflammatory molecule IL-12p40/p 70 , indicating that most MOG-containing cells display an anti-inflammatory phenotype (Table 2). In contrast, none of the MAP-2containing cells expressed IL-1ra and TGF- $\beta$, while the majority of the cells (86-100\%) expressed IL-12p40/p70 (Fig. 6c) and TNF- $\alpha$ (Fig. 6d), indicating a pro-inflammatory phenotype (Table 2). These data were paralleled in the CLN of EAE-affected rhesus monkeys, where $50-95 \%$ of the MOG-containing cells expressed IL-1 ra and 13-47\% expressed IL-12p40/p70, whereas $75-94 \%$ of the MAP-2containing cells expressed IL-12p40/p70 and none expressed IL-1ra.
Tissues were isolated $24 \mathrm{~h}(n=5)$ and $72 \mathrm{~h}(n=5)$ after MCAO, 7 days after ECL $(n=5), 7$ days after FNA $(n=3)$, and after 6 weeks of cuprizone treatment $(\mathrm{Cup} ; n=3)$. Cells were quantified in at least two sections of each tissue. Data represent the mean number of positive cells \pm SEM. ${ }^{*} p<0.05$

Part of MOG-containing cells in CLN of MS patients express CCR7, whereas MAP-2-containing cells do not express CCR7

Drainage of CNS antigens to the CLN may either occur as soluble proteins or within phagocytes [16, 47]. We have previously shown that myelin antigen-containing cells in rhesus monkey CLN express the chemokine receptor CCR7 [21], which mediates leukocyte homing to draining lymph nodes. Similarly, we observed that $20-42 \%$ of MOGcontaining cells in human MS CLN expressed CCR7, whereas none of the MAP-2-containing cells expressed this 
Fig. 4 MAP-2-containing cells in human MS CLN are immunocompetent APC. Immunofluorescent MAP-2 staining in human MS CLN (red) and staining for the APC markers MHC class II (green; a) and CD40 (green; b). Overlay shows coexpression of MAP-2 with MHC class II and CD40, which was observed in $90 \%$ to $100 \%$ of the MAP-2-positive cells. Nuclei are stained with DAPI (blue). Stainings were performed on two sections of CLN from three different MS patients. Scale bars $5 \mu \mathrm{m}$
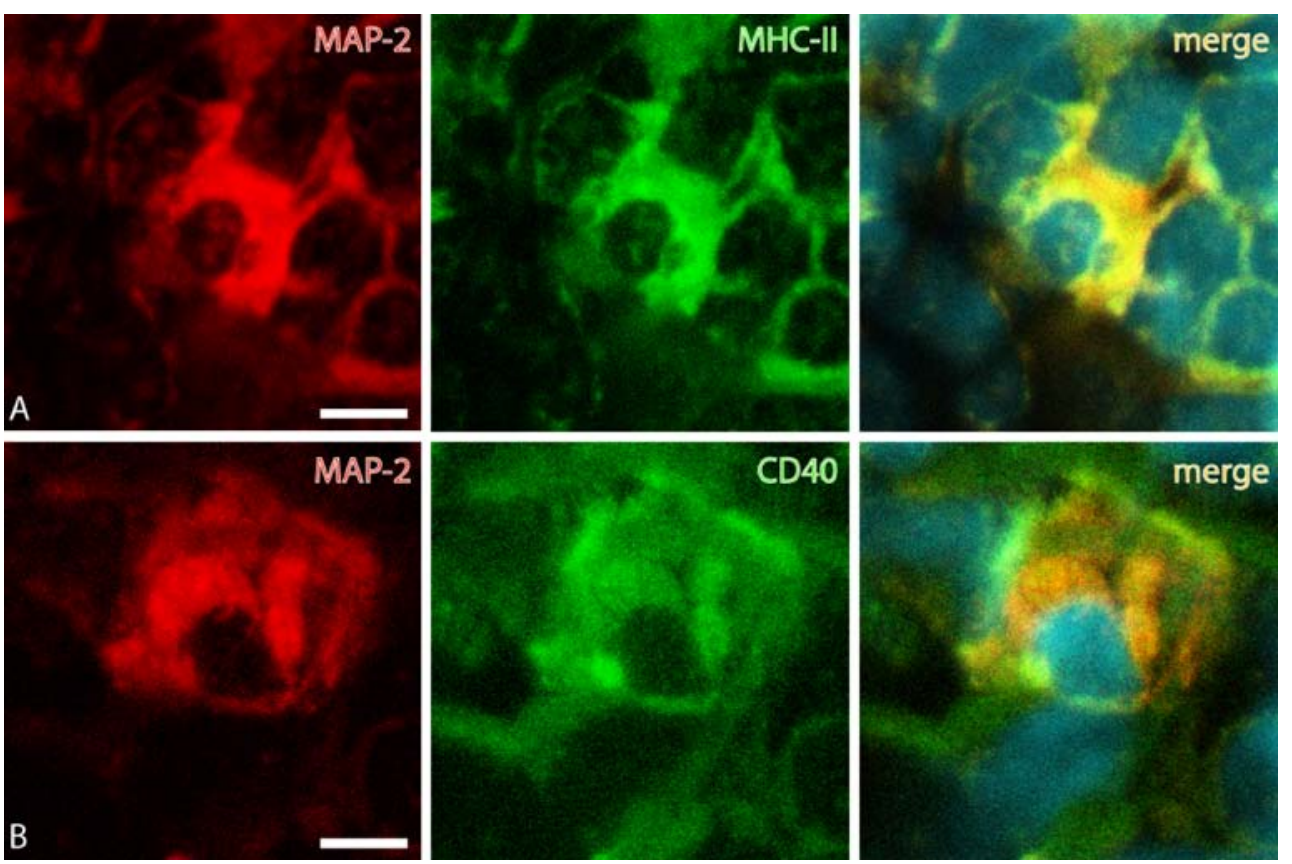

marker (Table 2). These data were paralleled in the CLN of EAE-affected rhesus monkeys, in which 20-46\% of MOGcontaining cells expressed CCR7, and MAP-2-containing cells did not express CCR7.

To investigate whether CCR7 expression is induced by the uptake of myelin antigens, we incubated human monocyte-derived macrophages from healthy donors in vitro with human myelin and determined CCR7 mRNA expression and CCR7 surface protein expression. We observed a time-dependent increase of CCR7 mRNA expression after myelin ingestion. As compared to control macrophages, myelin-laden macrophages demonstrated a $38.4 \pm 4.2$-fold increase in CCR7 mRNA expression after $24 \mathrm{~h}$ of myelin ingestion, which was reduced to a $6.3 \pm 0.9$-fold increase after 7 days of myelin ingestion. In addition to mRNA, CCR7 surface protein expression was also increased after myelin ingestion (data not shown).

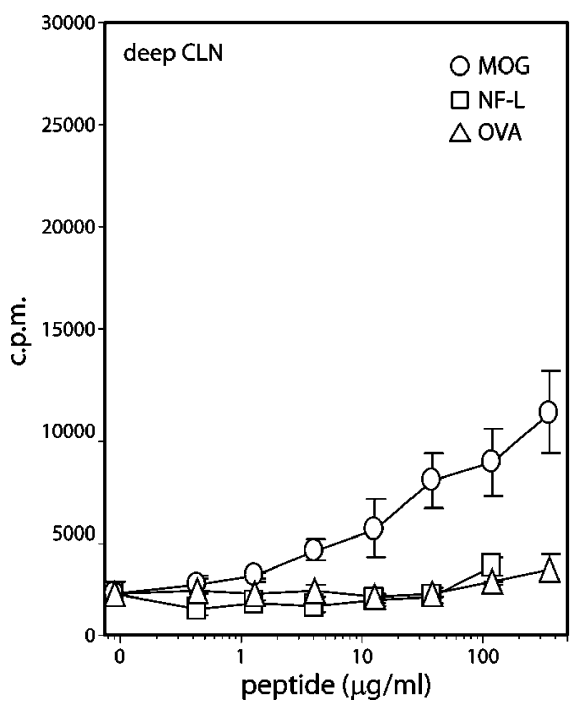

Fig. 5 Drainage of neuronal antigens to CLN in MOG-peptide-induced EAE does not elicit a detectable NF-L-specific $\mathrm{T}$ cell response. Stimulation of lymph node cells from deep CLN, superficial CLN, and LLN from EAE-affected C57BL/6 and Biozzi ABH mice with rmNF-L, $\mathrm{MOG}_{35-55}$, and ovalbumin demonstrates a dose-dependent proliferation against the myelin-derived peptide MOG, whereas no
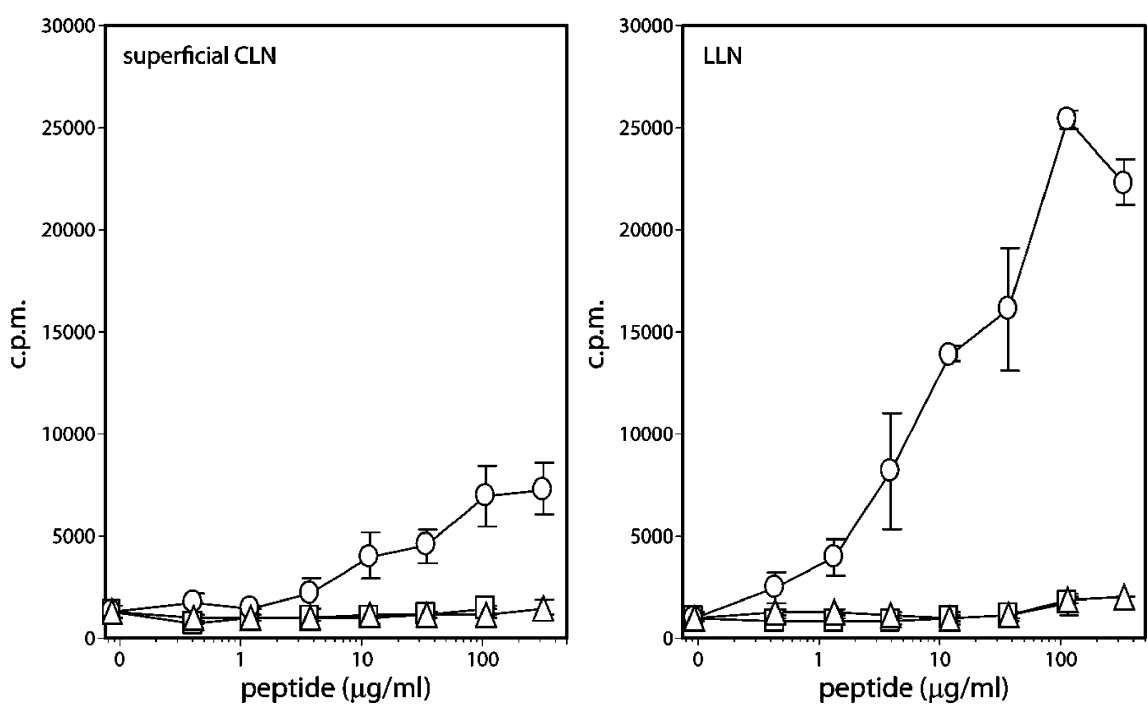

proliferation was observed against NF-L and ovalbumin. Lymph nodes of five to ten EAE-affected mice were pooled per experiment to obtain enough cells for restimulation. Results are presented as mean with the standard deviation of triplicates and are representative for three independent experiments using two different MOG-peptideinduced EAE models 
Fig. 6 Differential expression of pro- and anti-inflammatory molecules by MAP-2- and MOG-containing cells in human MS CLN. Immunofluorescent labeling of MOG (green) and the anti-inflammatory molecules IL-1ra (red; a) and TGF- $\beta$ (red; b) and immunofluorescent labeling of MAP-2 (red) and of the pro-inflammatory molecules IL-12p40/p70 (green; c), and TNF- $\alpha$ (green; $\mathbf{d})$ in human MS CLN. The overlays show colocalization of MOG and the antiinflammatory molecules IL-1ra and TGF- $\beta$, which was observed in $90 \%$ to $100 \%$ of the MOG-positive cells, and colocalization of MAP-2 and the pro-inflammatory molecules IL$12 \mathrm{p} 40 / \mathrm{p} 70$ and TNF- $\alpha$, which was observed in $86 \%$ to $100 \%$ of the MAP-2-positive cells. Nuclei are stained with DAPI (blue). Results are representative for two sections of CLN from an MS patient for double stainings of MOG with TGF- $\beta$ and TNF$\alpha$ and of MAP- 2 with TGF- $\beta$ and for at least two sections of CLN from three different MS patients for double stainings of MAP-2 with IL-12p40/p70, TNF- $\alpha$, and IL-1ra and double stainings of MOG with IL-1ra and IL-12p40/p70. Scale bars $5 \mu \mathrm{m}$
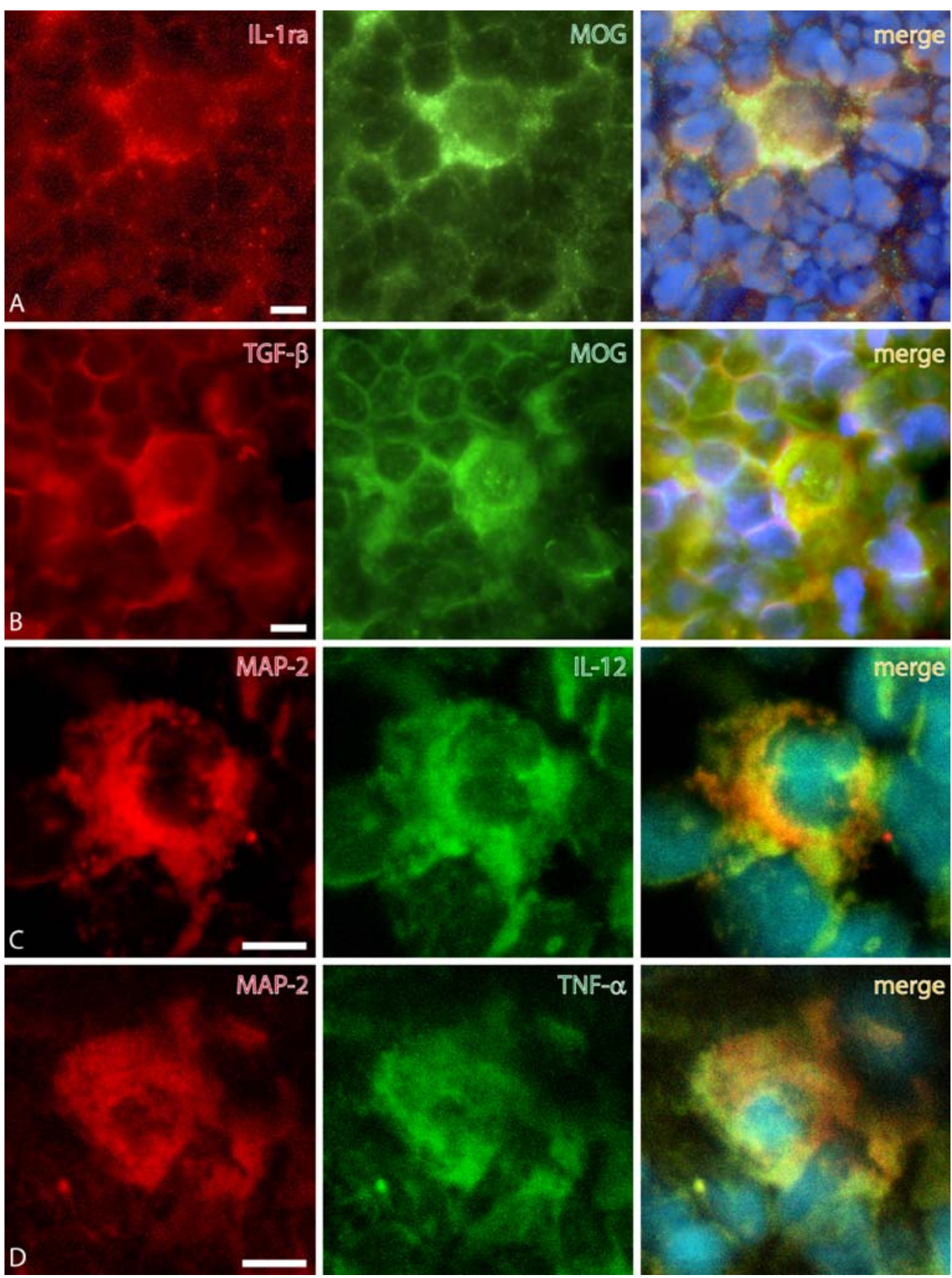

Finally, we assessed whether CCR7 expression affects the drainage of CNS antigens to CLN. To this end, we compared the number of CNS antigen-containing cells in the deep and superficial CLN of EAE-affected CCR7deficient and wild-type mice. In our hands, CCR7-deficient mice developed mild EAE and CLN of these mice were therefore compared to CLN from wild-type mice with comparable EAE symptoms. Unexpectedly, the numbers of both myelin and neuronal antigen-containing cells in CLN of EAE-affected CCR7-deficient mice were not statistically different as compared to wild-type mice (Table 3).

\section{Discussion}

Interaction between the brain and the secondary lymphoid organs allows regulation of immune responses in the brain [48]. This is exemplified by the crucial role of CLN in brain lesion expansion in cryolesion-enhanced EAE in rats [20] and by the presence of myelin antigens in APC in CLN of MS patients and EAE-affected rhesus monkeys and common marmoset monkeys [21, 22]. The current study assessed whether neuronal antigens also drain to the CLN after neuronal damage in the CNS. 
Table 2 Contrasting functional phenotype of MAP-2 versus MOG-containing cells in human MS CLN

\begin{tabular}{|c|c|c|c|c|c|}
\hline & \multicolumn{2}{|c|}{ Pro-inflammatory molecules } & \multicolumn{2}{|c|}{ Anti-inflammatory molecules } & \multirow{2}{*}{$\begin{array}{l}\text { Lymph node homing potential } \\
\text { CCR7 }\end{array}$} \\
\hline & IL-12p $40 / p 70$ & TNF- $\alpha$ & IL-1ra & TGF- $\beta$ & \\
\hline MAP-2 & ++++ & ++++ & - & - & - \\
\hline MOG & + & $+/-$ & ++++ & +++ & + \\
\hline
\end{tabular}

Quantification of double labeling of cells in CLN sections of MS patients. $-0 \%,+/-1-20 \%,+21-40 \%,++41-60 \%,+++61-80 \%,++++81-100 \%$ of the cells coexpressing both molecules. Results are representative for two sections of CLN from an MS patient for double stainings of MOG with TGF- $\beta$ and TNF- $\alpha$ and of MAP-2 with TGF- $\beta$ and for at least two sections of CLN from three different MS patients for double stainings of MAP-2 with IL-12p40/p70, TNF- $\alpha$, IL-1ra, and CCR7 and double stainings of MOG with IL-1ra, IL-12p40/p70, and CCR7.

MS is both clinically and pathologically a heterogeneous disease demonstrating various degrees of neuronal damage. The obtained CLN tissues were therefore from patients at various disease stages. To further determine drainage in a more controlled setting with defined disease stages, we used a variety of EAE models and models of noninflammatory CNS insult, representing different degrees of neuronal damage. We report here that neuronal antigens are present in CLN of MS patients and of animals after induction of EAE, MCAO, ECL, and FNA. In rhesus monkeys and Biozzi $\mathrm{ABH}$ mice, animals in which $\mathrm{EAE}$ results in significant neuronal damage within the CNS, the quantity of neuronal antigen-containing cells in the CLN reflected the intensity of neuronal damage in the CNS. Furthermore, qualitative and quantitative drainage of CNS antigens followed the type and extent of CNS damage in mice after MCAO, ECL, FNA, and cuprizone treatment. Interestingly, the frequency of CNS antigens in the CLN was high $24 \mathrm{~h}$ after MCAO and reduced $72 \mathrm{~h}$ after MCAO, indicating that drainage occurs rapidly but transient following CNS damage. This transient CNS drainage might also cause the few CNS antigen-containing cells in the CLN of the ECL and FNA model, which were isolated 7 days after CNS damage induction. These data extend our previous data and demonstrate that, following CNS damage, both myelin and neuronal antigens drain to CLN.

The presence of neuronal antigen-containing cells in CLN of control subjects was not unexpected and may be due to innervation of the CLN [49], expression of neuronal antigens by the cells themselves [41, 42], or to aging. The

Table 3 CCR7 deficiency does not affect CNS antigen load in CLN

\begin{tabular}{lllll}
\hline & MOG & PLP & MAP-2 & NF-L \\
\hline WT & $10.3 \pm 10.6$ & $0.8 \pm 1.1$ & $3.3 \pm 4.6$ & $1.5 \pm 2.1$ \\
CCR7 deficient & $29.7 \pm 15.7$ & $8.6 \pm 6.1$ & $4.7 \pm 4.2$ & $4.8 \pm \pm 7.1$ \\
\hline
\end{tabular}

Quantification of CNS antigen-containing cells in sections of deep CLN from four EAE-affected wild-type mice and four EAE-affected CCR7-deficient mice. Numbers represent mean number of cells per square millimeter \pm standard deviation of four sections per animal. frequency of neuronal antigen-containing cells in CLN from control subjects seems to differ between species, which might be due to differential neuronal turnover rates between species or differential expression levels of neuronal antigens by the cells.

To investigate drainage routes from the brain to the CLN, we used different non-inflammatory CNS damage models [31, 33, 44-46]. In cuprizone-treated animals, numerous cells containing myelin antigens were observed in the deep CLN, whereas such cells were observed only occasionally in the superficial CLN. We have found the same drainage route in EAE-affected mice, where we observed high numbers of neuronal antigen-containing cells in the deep CLN but hardly in the superficial CLN. These data indicate that CNS antigens preferentially drain to the deep CLN. In contrast, both the deep CLN as well as the superficial CLN of MCAO-treated mice contained numerous CNS antigens. This may be caused by a different drainage route as the result of the massive CNS damage or by the fact that this massive CNS damage has destroyed (part of) the drainage route. Myelin antigens were also observed in the LLN of cuprizone-treated mice, which are likely derived from the spinal cord, in which demyelination also takes place as is the case in MS and EAE. In fact, whereas CLN are crucial in brain lesion expansion in cryolesion-induced EAE in rats, they have no effect on lesion expansion in the lumbar part of the spinal cord [20], suggesting distinct functional relationships between CNS compartments and their local draining lymph nodes.

The nature of immune responses against CNS antigens in the CLN might be dictated by the functional phenotype of the CNS antigen-containing cells. We therefore determined the phenotype of myelin and neuronal antigen-containing cells in human MS CLN. Neuronal antigen-containing cells in MS CLN expressed the APC markers MHC class II and CD40, indicating that these cells are equipped for antigen presentation to $\mathrm{T}$ lymphocytes. Furthermore, neuronal antigen-containing cells were observed in the paracortex of the lymph node, where APC encounter and activate naïve $\mathrm{T}$ cells. Indeed, $\mathrm{T}$ cell responses against neuronal antigens have been demonstrated in MS patients and EAE- 
affected animals [8-10], and T cell-mediated EAE symptoms can be induced by immunization with neuronal antigens $[11,13,14]$. Despite this, we did not detect $T$ cell proliferation against NF-L in CLN from EAE mice immunized with $\mathrm{MOG}_{35-55}$ or $\mathrm{MOG}_{8-21}$. The lack of $\mathrm{T}$ cell proliferation we consistently found might be due to the absence of intermolecular spreading or to the fact that the draining antigens may act immunosuppressively on proliferation within the draining lymph nodes.

The current study shows that phagocytes containing the neuronal antigen MAP-2 in CLN of MS patients and EAEaffected rhesus monkeys had a pro-inflammatory phenotype. In contrast, the majority of phagocytes containing the myelin antigen MOG demonstrated an anti-inflammatory phenotype, suggesting a relation with the anti-inflammatory myelinladen foamy macrophages present within MS lesions [38]. This differential expression of pro- and anti-inflammatory molecules likely influences the type of immune response against these antigens. The difference in functional phenotype between MAP-2 and MOG-containing cells may be the consequence of the inflammatory status of the microenvironment in which the cells have taken up their antigens. Alternatively, the nature of the phagocytosed antigen may direct the immunophenotype of the cell into a pro- or antiinflammatory mode of action.

As both myelin and neuronal antigens are found in CLN, the question arises how these antigens reach these lymph nodes. The two likely mechanisms are either as soluble antigen or by active transport within phagocytosing cells $[16,17]$, such as the anti-inflammatory foamy macrophages within MS lesions [38]. Since anti-inflammatory macrophages express the lymph node homing receptor CCR7 [50], we determined whether a CCR7-dependent mechanism could be involved. This study shows that, similar to APC in MS brain as well as MOG-containing cells in EAEaffected rhesus CLN [21, 51], myelin-containing cells in human MS CLN and in vitro express CCR7, but MAP-2containing cells do not. CLN from EAE-affected CCR7deficient mice contain slightly more myelin and neuronal antigens as compared to CLN from EAE-affected wild-type mice, indicating that CCR7 is not necessarily involved. This strongly suggests that either other chemokine receptors are able to guide cell migration to the CLN or that CNS antigens drain as soluble antigens through CSF to the CLN. This hypothesis is supported by increased free neuronal proteins in CSF of MS patients and EAE mice as compared to healthy controls $[52,53]$.

In conclusion, we here report that neuronal antigencontaining cells are present in CLN during MS and in various animal models for CNS damage. The frequencies of these cells correlated with the extent of neuronal damage. In addition, neuronal antigen-containing cells in human MS CLN are present in functionally different APC subsets as compared to the majority of myelin antigen-containing APC. The presence of neuronal antigens in APC with a proinflammatory phenotype and of myelin antigens in APC with an anti-inflammatory phenotype points at a different potential to activate functionally distinct $\mathrm{T}$ cell subsets.

Acknowledgements The authors thank the Netherlands Brain Bank (coordinator Dr. R. Ravid) and the UK Multiple Sclerosis Tissue Bank Charing Cross Campus for supplying brain tissue, Dr. Christiane Nolte for providing FNA tissues, and T. van Os for microphotographs. This work was supported by grants of the Dutch MS Research Foundation (MS-01-471, MS-01-457, MS-00-417, and MS-02-490).

Open Access This article is distributed under the terms of the Creative Commons Attribution Noncommercial License which permits any noncommercial use, distribution, and reproduction in any medium, provided the original author(s) and source are credited.

\section{References}

1. Ferguson B, Matyszak MK, Esiri MM, Perry VH (1997) Axonal damage in acute multiple sclerosis lesions. Brain 120:393-399

2. Sospedra M, Martin R (2005) Immunology of multiple sclerosis. Annu Rev Immunol 23:683-747

3. Huizinga R, Linington C, Amor S (2008) Resistance is futile: antineuronal autoimmunity in multiple sclerosis. Trends Immunol 29:54-60

4. Silber E, Semra YK, Gregson NA, Sharief MK (2002) Patients with progressive multiple sclerosis have elevated antibodies to neurofilament subunit. Neurology 58:1372-1381

5. Eikelenboom MJ, Petzold A, Lazeron RH, Silber E, Sharief M, Thompson EJ, Barkhof F, Giovannoni G, Polman CH, Uitdehaag BM (2003) Multiple sclerosis: neurofilament light chain antibodies are correlated to cerebral atrophy. Neurology 60:219-223

6. Bartoš A, Fialova L, Soukupova J, Kukal J, Malbohan I, Pit'ha J (2007) Antibodies against light neurofilaments in multiple sclerosis patients. Acta Neurol Scand 116:100-107

7. Bartoš A, Fialova L, Soukupova J, Kukal J, Malbohan I, Pit'ha J (2007) Elevated intrathecal antibodies against the medium neurofilament subunit in multiple sclerosis. J Neurol 254:20-25

8. Polak T, Schlaf G, Scholl U, Krome-Cesar C, Mader M, Felgenhauer K, Weber F (2001) Characterization of the human $\mathrm{T}$ cell response against the neuronal protein synapsin in patients with multiple sclerosis. J Neuroimmunol 115:176-181

9. Forooghian F, Cheung RK, Smith WC, O'Connor P, Dosch HM (2007) Enolase and arrestin are novel nonmyelin autoantigens in multiple sclerosis. J Clin Immunol 27:388-396

10. Furlan R, Brambilla E, Sanvito F, Roccatagliata L, Olivieri S, Bergami A, Pluchino S, Uccelli A, Comi G, Martino G (2003) Vaccination with amyloid-beta peptide induces autoimmune encephalomyelitis in C57/BL6 mice. Brain 126:285-291

11. Mor F, Quintana F, Mimran A, Cohen IR (2003) Autoimmune encephalomyelitis and uveitis induced by $\mathrm{T}$ cell immunity to self beta-synuclein. J Immunol 170:628-634

12. Aktas O, Smorodchenko A, Brocke S, Infante-Duarte C, Topphoff US, Vogt J, Prozorovski T, Meier S, Osmanova V, Pohl E, Bechmann I, Nitsch R, Zipp F (2005) Neuronal damage in autoimmune neuroinflammation mediated by the death ligand TRAIL. Neuron 46:421-432

13. Rosenmann H, Grigoriadis N, Karussis D, Boimel M, Touloumi O, Ovadia H, Abramsky O (2006) Tauopathy-like abnormalities and 
neurologic deficits in mice immunized with neuronal tau protein. Arch Neurol 63:1459-1467

14. Huizinga R, Heijmans N, Schubert P, Gschmeissner S, 't Hart BA, Herrmann H, Amor S (2007) Immunization with neurofilament light protein induces spastic paresis and axonal degeneration in Biozzi ABH mice. J Neuropathol Exp Neurol 66:295-304

15. McMahon EJ, Bailey SL, Castenada CV, Waldner H, Miller SD (2005) Epitope spreading initiates in the CNS in two mouse models of multiple sclerosis. Nat Med 11:335-339

16. Karman J, Ling C, Sandor M, Fabry Z (2004) Initiation of immune responses in brain is promoted by local dendritic cells. $\mathrm{J}$ Immunol 173:2353-2361

17. Mohindru M, Kang B, Kim BS (2004) Functional maturation of proteolipid protein(139-151)-specific Th1 cells in the central nervous system in experimental autoimmune encephalomyelitis. J Neuroimmunol 155:127-135

18. Heppner FL, Greter M, Marino D, Falsig J, Raivich G, Hovelmeyer N, Waisman A, Rulicke T, Prinz M, Priller J, Becher B, Aguzzi A (2005) Experimental autoimmune encephalomyelitis repressed by microglial paralysis. Nat Med 11:146-152

19. Greter M, Heppner FL, Lemos MP, Odermatt BM, Goebels N, Laufer T, Noelle RJ, Becher B (2005) Dendritic cells permit immune invasion of the CNS in an animal model of multiple sclerosis. Nat Med 11:328-334

20. Phillips MJ, Needham M, Weller RO (1997) Role of cervical lymph nodes in autoimmune encephalomyelitis in the Lewis rat. J Pathol 182:457-464

21. de Vos AF, van Meurs M, Brok HP, Boven LA, Hintzen RQ, van der Valk P, Ravid R, Rensing S, Boon L, 't Hart BA, Laman JD (2002) Transfer of central nervous system autoantigens and presentation in secondary lymphoid organs. J Immunol 169:5415-5423

22. Fabriek BO, Zwemmer JN, Teunissen CE, Dijkstra CD, Polman CH, Laman JD, Castelijns JA (2005) In vivo detection of myelin proteins in cervical lymph nodes of MS patients using ultrasound-guided fineneedle aspiration cytology. J Neuroimmunol 161:190-194

23. Kerlero de Rosbo N, Brok HP, Bauer J, Kaye JF, 't Hart BA, BenNun A (2000) Rhesus monkeys are highly susceptible to experimental autoimmune encephalomyelitis induced by myelin oligodendrocyte glycoprotein: characterisation of immunodominant T- and B-cell epitopes. J Neuroimmunol 110:83-96

24. de Bakker NP, van Erck MG, Otting N, Lardy NM, Noort RC, 't Hart BA, Jonker M, Bontrop RE (1992) Resistance to collagen-induced arthritis in a nonhuman primate species maps to the major histocompatibility complex class I region. J Exp Med 175:933-937

25. 't Hart BA, Bauer J, Muller HJ, Melchers B, Nicolay K, Brok H, Bontrop RE, Lassmann H, Massacesi L (1998) Histopathological characterization of magnetic resonance imaging-detectable brain white matter lesions in a primate model of multiple sclerosis: a correlative study in the experimental autoimmune encephalomyelitis model in common marmosets (Callithrix jacchus). Am J Pathol 153:649-663

26. Brok HP, Uccelli A, Kerlero De Rosbo N, Bontrop RE, Roccatagliata L, de Groot NG, Capello E, Laman JD, Nicolay K, Mancardi GL, Ben-Nun A, Hart BA (2000) Myelin/oligodendrocyte glycoprotein-induced autoimmune encephalomyelitis in common marmosets: the encephalitogenic T cell epitope pMOG24-36 is presented by a monomorphic MHC class II molecule. J Immunol 165:1093-1101

27. Baker D, O’Neill JK, Gschmeissner SE, Wilcox CE, Butter C, Turk JL (1990) Induction of chronic relapsing experimental allergic encephalomyelitis in Biozzi mice. J Neuroimmunol 28:261-270

28. Amor S, Baker D, Groome N, Turk JL (1993) Identification of a major encephalitogenic epitope of proteolipid protein (residues 56-70) for the induction of experimental allergic encephalomy- elitis in Biozzi $\mathrm{AB} / \mathrm{H}$ and nonobese diabetic mice. J Immunol 150:5666-5672

29. Höpken UE, Droese J, Li JP, Joergensen J, Breitfeld D, Zerwes HG, Lipp M (2004) The chemokine receptor CCR7 controls lymph node-dependent cytotoxic $\mathrm{T}$ cell priming in alloimmune responses. Eur J Immunol 34:461-470

30. Visser L, Jan de Heer H, Boven LA, van Riel D, van Meurs M, Melief MJ, Zahringer U, van Strijp J, Lambrecht BN, Nieuwenhuis EE, Laman JD (2005) Proinflammatory bacterial peptidoglycan as a cofactor for the development of central nervous system autoimmune disease. J Immunol 174:808-816

31. Prass K, Meisel C, Hoflich C, Braun J, Halle E, Wolf T, Ruscher K, Victorov IV, Priller J, Dirnagl U, Volk HD, Meisel A (2003) Strokeinduced immunodeficiency promotes spontaneous bacterial infections and is mediated by sympathetic activation reversal by poststroke T helper cell type 1-like immunostimulation. J Exp Med 198:725-736

32. Rappert A, Bechmann I, Pivneva T, Mahlo J, Biber K, Nolte C, Kovac AD, Gerard C, Boddeke HW, Nitsch R, Kettenmann H (2004) CXCR3-dependent microglial recruitment is essential for dendrite loss after brain lesion. J Neurosci 24:8500-8509

33. Hiremath MM, Saito Y, Knapp GW, Ting JP, Suzuki K, Matsushima GK (1998) Microglial/macrophage accumulation during cuprizone-induced demyelination in C57BL/6 mice. J Neuroimmunol 92:38-49

34. Laman JD, van Meurs M, Schellekens MM, de Boer M, Melchers B, Massacesi L, Lassmann H, Claassen E, 't Hart BA (1998) Expression of accessory molecules and cytokines in acute EAE in marmoset monkeys (Callithrix jacchus). J Neuroimmunol 86:30-45

35. Claassen E, Jeurissen SHM (1996) A step by step guide to in situ immune response analysis of lymphoid tissues by immunohistochemical methods, Weir's handbook of experimental immunology. Blackwell Science, Cambridge

36. Laman JD, Visser L, Maassen CB, de Groot CJ, de Jong LA, 't Hart BA, van Meurs M, Schellekens MM (2001) Novel monoclonal antibodies against proteolipid protein peptide 139151 demonstrate demyelination and myelin uptake by macrophages in MS and marmoset EAE lesions. J Neuroimmunol 119:124-130

37. Visser L, Melief MJ, van Riel D, van Meurs M, Sick EA, Inamura S, Bajramovic JJ, Amor S, Hintzen RQ, Boven LA, t Hart BA, Laman JD (2006) Phagocytes containing a disease-promoting Toll-like receptor/Nod ligand are present in the brain during demyelinating disease in primates. Am J Pathol 169:1671-1685

38. Boven LA, Van Meurs M, Van Zwam M, Wierenga-Wolf A, Hintzen RQ, Boot RG, Aerts JM, Amor S, Nieuwenhuis EE, Laman JD (2006) Myelin-laden macrophages are anti-inflammatory, consistent with foam cells in multiple sclerosis. Brain 129: $517-526$

39. Norton WT, Poduslo SE (1973) Myelination in rat brain: method of myelin isolation. J Neurochem 21:749-757

40. Heins S, Wong PC, Muller S, Goldie K, Cleveland DW, Aebi U (1993) The rod domain of NF-L determines neurofilament architecture, whereas the end domains specify filament assembly and network formation. J Cell Biol 123:1517-1533

41. Yan WH, Cao MD, Liu JR, Xu Y, Han XF, Xing Y, Wang JZ (2005) Effects of EGF and bFGF on expression of microtubuleassociated protein tau and MAP-2 mRNA in human umbilical cord mononuclear cells. Cell Biol Int 29:153-157

42. Zhao LR, Duan WM, Reyes M, Keene CD, Verfaillie CM, Low WC (2002) Human bone marrow stem cells exhibit neural phenotypes and ameliorate neurological deficits after grafting into the ischemic brain of rats. Exp Neurol 174:11-20

43. 't Hart BA, Bauer J, Brok HP, Amor S (2005) Non-human primate models of experimental autoimmune encephalomyelitis: variations on a theme. J Neuroimmunol 168:1-12 
44. Kreutzberg GW (1996) Microglia: a sensor for pathological events in the CNS. Trends Neurosci 19:312-318

45. Kwidzinski E, Mutlu LK, Kovac AD, Bunse J, Goldmann J, Mahlo J, Aktas O, Zipp F, Kamradt T, Nitsch R, Bechmann I (2003) Self-tolerance in the immune privileged CNS: lessons from the entorhinal cortex lesion model. J Neural Transm Suppl 65:29-49

46. Irvine KA, Blakemore WF (2006) Age increases axon loss associated with primary demyelination in cuprizone-induced demyelination in C57BL/6 mice. J Neuroimmunol 175:69-76

47. Weller RO (1998) Pathology of cerebrospinal fluid and interstitial fluid of the CNS: significance for Alzheimer disease, prion disorders and multiple sclerosis. J Neuropathol Exp Neurol 57:885-894

48. Cserr HF, Knopf PM (1992) Cervical lymphatics, the blood-brain barrier and the immunoreactivity of the brain: a new view. Immunol Today 13:507-512

49. Bellinger DL, Lorton D, Lubahn C, Felten DL (2001) Innervation of lymphoid organs-association of nerves with cells of the immune system and their implications in disease. In: Ader R, Cohen N, Felten D (eds) Psychoneuroimmunology. Academic, New York, pp 55-111

50. Martinez FO, Gordon S, Locati M, Mantovani A (2006) Transcriptional profiling of the human monocyte-to-macrophage differentiation and polarization: new molecules and patterns of gene expression. J Immunol 177:7303-7311

51. Kivisakk P, Mahad DJ, Callahan MK, Sikora K, Trebst C, Tucky B, Wujek J, Ravid R, Staugaitis SM, Lassmann H, Ransohoff RM (2004) Expression of CCR7 in multiple sclerosis: implications for CNS immunity. Ann Neurol 55:627-638

52. Malmestrom C, Haghighi S, Rosengren L, Andersen O, Lycke J (2003) Neurofilament light protein and glial fibrillary acidic protein as biological markers in MS. Neurology 61:1720-1725

53. Norgren N, Edelstam A, Stigbrand T (2005) Cerebrospinal fluid levels of neurofilament light in chronic experimental autoimmune encephalomyelitis. Brain Res Bull 67:264-268

54. Amor S, Smith PA, Hart B, Baker D (2005) Biozzi mice: of mice and human neurological diseases. J Neuroimmunol 165:1-10

55. Tsunoda I, Tanaka T, Terry EJ, Fujinami RS (2007) Contrasting roles for axonal degeneration in an autoimmune versus viral model of multiple sclerosis: when can axonal injury be beneficial? Am J Pathol 170:214-226

56. Bechmann I, Peter S, Beyer M, Gimsa U, Nitsch R (2001) Presence of B7-2 (CD86) and lack of B7-1 (CD(80) on myelin phagocytosing MHC-II-positive rat microglia is associated with nondestructive immunity in vivo. FASEB J 15:1086-1088

57. Moran LB, Graeber MB (2004) The facial nerve axotomy model. Brain Res Brain Res Rev 44:154-178 